\title{
SPREADING DA'WAH IN ISLAM: EXPLORING THE CONCEPT OF TOURISM FROM THE QURANIC PERSPECTIVE
}

\author{
A. H. Usman*, W. F. R. Wan Mohamad, M. F. M. Abdul Mutalib \\ Faculty of Islamic Civilisation Studies, Kolej Universiti Islam Antarabangsa Selangor (KUIS), 43000, \\ Malaysia \\ *aburhamdi@kuis.edu.my
}

\begin{abstract}
Spreading $d a$ 'wah and all the efforts heading that direction should be made as a whole, as it represents the nature of Islam itself. Hence, da'wah should be a part of everyday life as humans, which is not restricted to a person's individual lifestyle. Da'wah requires an amount of men power of quality and quantity, excel in spiritual strength, open minded and professionalism. This research was made to analyse the factors of how the da'wah of Islam spread throughout the globe, while making tourism as one of the most common mediums for $d a^{\prime} w a h$. Using a descriptive document analysing method and proof from history, this research will reveal the impact of Islamic tourism in spreading the religion on a global scale as It is crucial to take this research seriously and give close attention to make Islam the centre of the attraction.
\end{abstract}

Keywords: Da'wah, Tourism, Conquer, Marriage, Trades

\section{INTRODUCTION}

During On the geographic terrain of the world, the Muslims nowadays are settled on a big scale of the map. They come from different nation, different race, skin colour, and speaks in a variety of languages. Although the differences are significant, they are all connected with a single knot build from a strong bond of religion, which is Islam (Fadhlullah, 2007) This means that Islam does not own by one race, one nation, one tribe. This clearly states that Islam was a religion, accepted by a majority of people, nationwide. But that does not discard the fact that a part of them do protest its existence in this world. Relating to the facts, this research will be done to try and unravel the factors that becomes the $\mathrm{x}$-factor on how the religion spread like fire all around the world, while investigating the effects of what has been left by history that can be witnessed until today.

\section{Conquer: The Glory Days of Islam and Its Contribution towards World Civilization}

Conquer or the beginning of Islam has been a key factor in contributing the vast-growing religion to spread around the globe, more efficiently and faster. When the religion arrived in an area where Islam is a nobody, it opens up the possibilities to attain more followers and converts in Islam.

War and conquer has been an issue for the Westerns to accuse that Islam was spread by cruelty and force. But, it has been proven that not even one verse from the Holy Quran or some historical moments that happen in the early history of Islam were based on cruelty and force (al-Usyairi, 2011). In fact, this issue has made the status of the religion in a threatening situation, as it becomes exposed to open attacks. For that reason, they have come to a conclusion between two choices, either they will let them get away with the crime while they will get weaker and weaker by the day, or they fight for what they believe is right, fighting and resisting enemy attacks that comes in their way (Dusuki, 1982). This means that Islam was forced to take part in the war, to protect the religion and in other words, fight for the solidarity of freedom for religion.

Islam grew bigger on every part of the globe, has put an effect on the civilization of other countries. Hence, this proves on how the religion has been a contributing factor to the civilization of successful countries, including in terms of Arts. Islamic Arts did not affect the Islamic Civilization only, it in fact contributed to another civilization as well. Janson H.W., a bachelor of Western Arts quoted in his masterpiece, 'Persian Painting in The John Rylands Library' that the Islamic Arts became a big influence on the Europeans back in the Middle Ages; influence of Arabic Ornaments, the 
reintroduction of Greek Philosophy, and science through the writings of Islamic Scholars (Manja \& Ahmad 1995).

The resurrection of the Westerners during the Renaissance has created a bit of a splash in the Western Civilization. The splash of Islamic Art has grown bigger along with the spread of religion itself, for example the famous Crusade, Andalusia and Sicily (Azizan, 1986). Islamic Architecture Designs were duplicated by the Westerns and it was detected since the 10th Century in a few places in North Spain, for example Leon, Castila, Galicia and Catalonia. In Andalusia and Granada, it is proven that a lot of Islamic Architectural Designs were built. Among the famous buildings in Granada was built during the Nariyyah Dynasty. The building was built because of the similarities or similarities between the Muslims and Non- Muslims on the 13 to 14 AD. In Granada, a lot of the architecture was inspired by Islamic Architecture, for example the Al-Hambra Castle, which represents as a landmark for Islam in Andalusia (Mohd, 2011).

There were a few signs of greatness in the influence of Islamic Architecture as we can witness the Church Door of Wastlen-Boulonhous in North France. The design was a similar copy of the bab alFath in Cairo (Manja \& Ahmad, 1995). While in India, Islam bloomed in the country with the mixture of Hindu and Persia in their architecture, that gave birth to the famous Taj Mahal, that possess a high value in art and is considered as one of the Seven Wonders of The World. The Taj Mahal was built from white marbles, inspired by Persian Architecture (Sayyed, 1987).

It is believed that the factor of Domination (Conquer) of Islam in other countries has played and important role in the spreading of Islam in a big scale. As the Islamic Government dominated an area, it will automatically influence the blooming of the religion in the region. Hence, landmarks were made by the previous Islamic dynasty that can be witnessed until today. The Islamic Architecture was created based on the mixture of different elements from different places in the world. Through this process, Islamic Designs have left a mark in Europe, Far East, and Asia. Islamic Arts were also recognized as a high-valued masterpiece in the eye of the world.

\section{Trades: An Effort to Polish Islamic Civilization}

A big part of Islamic Da'wah growing in the hearts of humans is through direct trades. In fact, International Trades have become the trump card in Islam's success. A good trader does not trade in items and money only, they trade in knowledge and share more about Islam from other countries such as China, India, Far East, etc.

Leur (1960) wrote in his book Indonesian Trade and Society that the Arabic and Persian Traders back then went to China through trades. They resided in Canton since the 4th century. Even old Chinese scriptures have mentioned about the Arab Traders living in their country in the year 618 and 626 . During the period, some of the Islamic Laws were implemented due to their presence in the country. The Arabs also helped maintain the presence of other countries such as Persia, The Jews, Armenia and Nestorian Christians. In the middle of the hectic route of tradings taken by the Muslims back then, settlements were present along the way and one of them is in West Sumatra in the year 674.

According to Arnold (1981), the $d a^{\prime} i$ or agents of $d a^{\prime} w a h$ were not labelled as imperialism or war as how it happened in the Middle East, South Asia and South Africa. To flip things over, traders were used as a medium to share the religion, bringing with them a good quality of tolerance and their similarities between humans. Traders from Arab, Persia and India, started to open up their market in the Nusantara since the year 8 or $9 \mathrm{AD}$.

In terms of Nusantara, history has proven that the Islamic Traders played an important role in the $d a$ 'wah movement of Islam. There is a big possibility that Islam was spread in the Malay Region since the early years of Hijriah. This is based on a report that the Arabs were spreading their market of trade in the Malay Region and China as well. Their role in $d a$ 'wah was divided into two. The first was their hard work and effort in spreading Islam to the locals, while the second role was they became the mode of transportation for Islamic Preachers to spread Islam along the way, from one dock to another (Arnold, 1974). 
Spreading Islam through trading has given a big effect in the movement since the 14 AD until $17 \mathrm{AD}$ as we can witness Islam blooming fast as lightning. For example Java and Champa, there are signs of Arab settlements. This has been proven with the old tombs from the Arabs that existed around the year 1028 in Java and 1039 in Champa. With the info given, these facts showed that a good bond of relationship and interaction existed between the Arabs and the locals for a very long time (Leur, 1960). Pires (1944) stated that the movement of preaching or $d a^{\prime}$ wah of Islam in the Malaya (Malay Region) took place in peace, using trade as a medium, as they settled down with the locals and some even married with the locals. The best chance for these Islamic Traders to spread Islam were through these 3 categories, which is by building a good relationship with the leader of the settlement or labour, the King, or the Local Authorities. Aside from that, they can use marriage as a medium and build a strong bond of ties with the locals there from different areas.

To tie the knot, it is concluded that the web of connection created by the Islamic Traders which connected Arab, Persia, India and Nusantara has existed a few centuries ago since the year BC until the birth of Islam which was around 8 or $9 \mathrm{AD}$. With trading as a factor of $d a$ 'wah, the traders back then have successfully converted a lot of locals into accepting Islam through various ways, such as building a good relationship with the local authority and local traders from other countries. Some of them even settled down and lived for some period of time with the locals, just to convince them that Islam is the way of life. Trading has become a big factor in the medium of $d a$ 'wah globally and internationally.

\section{Marriage: International Ties of Love in Spreading Islam}

Marriage was also a key factor in spreading Islam, including the Nusantara region as well. These marriages took place in two ways, first and foremost was a marriage between the traders and the local daughters, including the princess of the country as well. Secondly, a marriage between two royal families between Muslim and non-Muslim. For instance, the King of Melaka, Parameswara (Megat Iskandar Syah) got married to the Princess of Pasai in 1414, whereas they did not create a bigger bond of ties between the families, but the whole country of Melaka converted to Islam due to the marriage. Next, the marriage between the Princess of Champa with an Arabic Missionary named Ibrahim alGhazi bin Jamal al-Din Hussin or people like to call him by the name Ibrahim Asmarkandhi and a prince was born named Raden Rahmat (Abdul Rahman, 2000). The birth of Price Raden has brought the wave of change in the Javanese community as they were able to spread Islam in a fast pace and converted a majority of the community to Islam (Arnold, 1974).

With the points given, it is concluded that marriage has become a major factor in the line of spreading Islam. When the two countries built the bridge of relationship, this has encouraged both of the countries to accept Islam. Following this event, when the King and his minister have become Muslims, the people of the country will follow their footsteps as well.

\section{Religious Doctrine: A Factor of Attraction for the people of Nusantara}

Islam is a comprehensive religion that has rules, discipline and kindness in all aspects of human life (Abdullah, 1992). Among the benefits of it that's very understandable, it is not beyond human intelligence, always rational and very suitable for all human beings in every time and place. Islam is a religion that emphasizes the question of faith (Muhammad, 1998). Aside from a social perspective, Islam also teaches that every human is equal, and the one that differentiates from one and another is their faith, for the nobles of all humans are the ones who are the most pious towards Allah. In the same time, Islam can guarantee social justice, emphasizes on the relationship and ties between humans, helping each other, respect one another, unite together as one, etc. With these values that Islam possess, it is very acceptable among people everywhere. Even history has proven a lot of the traders back then were also Sufis and Preachers that become the light of Islam.

These groups of people are Islamic Scholars that hold on tight to the religion and practice the religion without fail. Their attitude and characters became the centre of attraction and they were respected by the Nusantara community. In the earlier phases, these groups performed their obligations to the Islamic Law by wearing clean clothes, took good care of their personal cleanliness, clothing, their house and 
their place of worship (Arnold, 1974: 383). The feel of harmony created by the bonds from the scholars and the traders who accepted Islam has made them an influenced group among the local settlers (Auni, 1991).

Van Den Berg in his book Le Hadhramaut ed lest Aran en Indie stated that the most influenced groups that has been a played a big role in the da'wah of Islam are the Sayyids and Syariffs. With them as the medium, Islam was spread widely among the royal families of Hindu in Java, and others as well. In addition, there were other Arab Hadhramaut tribes, but they have no such influence (Al-Haddad, 2001: 210). In their initial stages, they are said to face opposition from the Hindu monks who use various witchcraft to break the da'wah and Islamic influence. With the help of Allah SWT, they made it through with His help. By then, more and more started to believe in Islam. During the times of Melaka, Aceh and Demak, the Sufis had a big influence in the royal family and ministers. For example, during the opening of Perlak, Samudera Pasai, Aceh, Melaka and others, the Scholars has been an important asset to the kingdom. A lot Scholars born in Aceh has been a big influence in spreading Islam, such as Hamzah Fansuri, Nur al-Din al-Ramiri, Abdul Rauf Singkel and Syams alDin al-Sumatra'i (Auni, 1991).

Based on the explanation above, this has shown that this has become a big factor that influenced the growth of Islam to all sides of the world, making it as an objective and a base in spreading Islam on a larger scale, and become a catalyst for other religious institution of the main stream in the world.

\section{Literature: A Proof of Da'wah in Nusantara}

Writing and Literature are proofs of Islamic da'wah specifically in the Nusantara. It was built bit by bit, starting with Islamic preaching done by the Traders and Missionaries (Abdul Basir, 2009). Books in Arabic like Tafseer, Hadith, Tasawwuf and Arabic Literature such as poems, poetry and etc., were translated by the scholar into the local language which Bahasa Melayu. It is to make sure that all the contents of the books can be understood easily and mastered by the Malays during the early stages of da'wah. History has witnessed that Sultan Malikuzh Zhahir, the King of Pasai has mastered Arabic fluently. He handled a lot of knowledge ceremony where a lot of big scholars attended. The Kings of Aceh have writings that run the Arab leaflets. The Chairman of the House was named Katib al-Muluk. Legislations made between these kingdoms and foreign countries are made in Arabic. All agreements were also written in Arabic (al-Haddad, 2001).

In the end, a lot of Islamic Figures in Writing amongst the scholars back then were determined to produce a masterpiece of art and literature with added Islamic values. And we can see it how it leaves a big effect in terms of translation into Arabic, as well as Jawi. The compilation process was made using Arabic Language too. It is proven on how the word that starts with "Beginning...", "he will/she will..", "by him/her" and most of the words that starts with a verb in the sentence (Rosmi \& Nurhasma, 2009). This has once again proven that Arabic Literature towards education, specifically in the Nusantara region has been solid and at the same time, attracts the interest in the community to learn Islam.

\section{TOURISM THROUGH AN ISLAMIC PERSPECTIVE}

Tourism in Arabic is known as al-siyahah, which means to travel to another country for exploring, sightseeing, recreational activities, witnessing something happening and etc. (Al-Arabiyyah, 2004). It also means to go around the world to pray and the cleanse the heart (Ibn Manzur, n.d., 24). Hence, the definition of tourism in terms of language does not mean by looking up for profit, working, or staying at a specific place for a long term of period.

Other words that can be similar or synonymous to al-siyahah is al-rihalah and al-safar. Al-Rihlah means to do something along a journey with a specific meaning. This word is treasured in the al-Quran with only verse ('Abd al-Baqi, 1945), which is in surah al-Quraisy, verse 2 that shows the norms of the Quraisy on doing their travels in hot and cold weather. This differs with the term al-safar that contains the meaning of travelling, but in a more general purpose (Abur \& Mazlan, 2014). The word 
itself was repeated in the al-Quran as much as 8 times ("Abd al-Baqi, 1945). With that, to get a better understanding of this topic, it must be elaborated into a few purpose of travelling or tourism in Islam.

The term travelling back in the old days was related to the surface of the Earth without a proper destination. It was not meant to be used for learning, whereas it was actually used by the community back then to travel as into torture themselves as a sign of piousty and believe it as a sign of worship (Ibn al-Jauzi, 1989). Hence, the Prophet Muhammad PBUH said that "There are no travels in Islam". This hadith was meant for the bad side or bad meaning of travelling, complaining and create havoc amidst the lives of humans (Ibn al-Athir, 1979). In other words, the reason was not suitable to the Islamic Law, whereas in the Quran travelling were meant to be abided by the law, such as fasting, learning and war (al-Buhuti, 1982).

With the problem occurred, Islam has made some improvements to create a better understanding for the term travelling in Islam such as:

i) Worship, thus requiring a journey to fulfil one of the religious demands, such as hajj and umrah in certain months. Hence, whenever a person comes to see the Prophet PBUH to ask for permission to travel, based on the old meaning, with the meaning of religious terms or to torment themselves, so the prophet PBUH will show them a better meaning for travel which he said "The Tourism of my people are doing jihad on the road of Allah, performing hajj and umrah" (Ibn Bashran, 1993).

This has been clear that the need to emphasize on tourism activities, even though sacrifices have to be made, either in terms of time, money, hardship, etc.

ii) Seek for knowledge, until it has become clear that in the beginning of Islam, travels for knowledge were highly acknowledged for the sake of knowledge and sharing it. In fact, well-known scholar scholars such as al-Khatibal-Baghdadi wrote a book called al-Rihlah fi Talab al-Hadith (The Journey of Knowledge for Hadith) which discussed on the tales of a person who travelled all over the place to obtain or even to gain just one hadith. Allah also said in Surah al-Tawbah verse 112 which proves that tourism means a journey to seek knowledge (al-Shawkani, 1993). Even though majority of the Quranic Exegetes has decided that this verse was meant for the ones who fast.

iii) Tadabbur, as explained in Surah al-An'am verse 11 which shows that Allah has ordered all human beings to travel and walk around the Earth to gain new knowledge and morals from the places being visited. For that, al-Qasini (1994) has stated that the main reason for tourism is to explore the rubbles and relics left by history, and make it as an advice, a moral so that it will benefit others.

With the reason above, Islam has set the reason for tourism as a way to stop and think about the beauty of Allah's creation, as it builds up the faith in the hearts of its followers towards Allah and as a motivation to perform their life obligations towards Allah.

iv) Da'wah, as how the Prophet PBUH and his Sahabat who went through thick and thin spreading Islam around the world just to make sure his followers will obtain guidance and follow the straight path.

The relationship between $d a$ 'wah and tourism can be proven by visiting old tombs. Shihab (1992) has made a few guidelines on what should be highlighted during the visit, as it does possess some moral values:

1) The visit must be under the circumstances of Islamic rules and not making it against the religion and culture, especially for those who are obsessed by it as it may bring shirk.

2) The visitors should give a sign of respect to the owner of the tomb as they have lived their lives until the end.

3) Moral values obtain from the tomb should be taken and know their contributions from their past life.

With the reason above, one of the implications that should be implemented by the person in charge are the quality of the workers that are knowledgeable and are capable to not just explain the history, the 
condition, the in and out of the place, but they must be able to touch the hearts of the tourist with good explanation and making them realize the true meaning of life.

\section{CONCLUSION}

Based on the fiction and facts above, it is concluded that the factors of $d a$ 'wah through conquering, trades, marriage, religious doctrine and literature has been a big influence in producing an effective $d a$ 'wah for Islam on a global scale. In fact, it has been the basic and base of spreading Islam all around the world.

Aside from that, tourism has been one of the activities that are encouraged in Islam. Aside from contributing to the country economically and financially, it has been one of the common mediums for $d a$ 'wah and to spread Islam. Da'wah does not limit to the outsiders or tourists, but also to the local community and people as they can know more about Islam with the same medium, closer than they think.

\section{REFERENCES}

Abdul Basir, A. (2009). Peminjaman kata bahasa Arab dalam bahasa Melayu. In Malaysia Conference on Arabic Studies and Islamic Civilization.

Abdul Rahman, A. (2000). Sejarah dan tamadun Asia Tenggara: Sebelum dan Sesusah pengaruh Islam. Utusan Publication and Distributor.

Abdullah, I. (1992). Islam di Nusantara: Khususnya di Tanah Melayu. Jabatan Perdana Menteri.

Abur, H. U. \& Mazlan, I. (2014). Al-Tafsir al-Mawdu'i: Lafaz al-Nafar dalam al-Quran. Penerbit UKM.

Al-Arabiyyah, M. A. L. (2004). al-Mucjam al-wasit. Maktabat al-Khanji.

al-Buhuti, M. Y. (1982). Kashshaf al-Qinac Min Matan al-Iqnac. Dar al-Fikr.

Al-Haddad, A. (2001). Sejarah masuknya Islam di Timur Jauh. PT. Lentara Basritama.

al-Qasimi, M. J. (1994). Mahasin al-ta'wil. Dar Ihya' al-Turath al-cArabi.

al-Shawkani, M. A. (1993). Fath al-qadir aljamic bayna fannay al-dirayah wa al-riwayah min cilm altafsir. Dar al-Hadith.

Al-Usairy, A. (2011). Sejarah Islam sejak zaman nabi Adam hingga abad XX. Akbarmedia.

Arnold, T. (1974). The preaching of Islam: A history of the Muslim faith. Constable.

Arnold, T. (1981). Sejarah dakwah Islam. Penerbit Widjaya.

Auni, A. (1991). Islam dalam sejarah politik dan pemerintahan di Alam Melayu. Nurin Enterprise.

Azizan, B. (1986). Pengenalan tamadun Islam di Andalus. Dewan Bahasa dan Pustaka.

cAbd al-Baqi, M. F. (1945). al-Mucjam al-mufahras li alfaz al-Qur'an al-Karim. Dar al-Hadith.

Dusuki, A. (1982). Ikhtisar perkembangan Islam. Dewan Bahasa dan Pustaka.

Fadhlullah, J. (2007). Islam di Asia Barat moden penjajahan dan pergolakan. Karisma Publications Sdn. Bhd

Ibn al-Athir, A. S. (1979). al-Nihayah fi Gharib al-Athar. Maktabah al-cIlmiyyah.

Ibn al-Jauzi, J. (1989). Talbis Iblis. Dar Maktabah al-Hayah.

Ibn Bashran, A. Q. (1999). Amali Ibn Bashran. Dar al-Watan.

Ibn Manzurr, M. (n.d.) Lisan al-cArab. Dar Sadir.

Leur, J. C. V. (1960). Indonesian trade and society: Essay in Asian social and economic history. Semur Bandung.

Manja, M. L \& Ahmad, S. M. N. (1995). Aspek-aspek kesenian Islam. Dewan Bahasa dan Pustaka.

Mohd. N. J. (2011). Tamadun Islam dan tamadun Asia. Sarjana Media.

Muhammad, U. E. (1998). The Muslim society as an information society. In Islam and Development in Asia. Perniagaan Normah, pp. 61-66.

Muslim, A. H. H. (n.d.) al-Jamic al-Sahih. Dar al-Jil.

Pires, T. (1944). The Suma oriental of Tome Pires. Kraus Reprint Limited.

Rosni, S., \& Nurhasma, M. S. (2009). Kesan terjemahan dalam pengajaran Bahasa Arab. In Malaysia Conference on Arabic Studies and Islamic Civilization, pp. 645-654.

Sayyed, H. N. (1987). Traditional Islam in the modern world. KPI Limited.

Shihab, M. Q. (1992). Membumikan al-Quran. Mizan. 